\title{
Nanoarchitectonics Can Save Our Planet: Nanoarchitectonics for Energy and Environment
}

\author{
Katsuhiko Ariga ${ }^{1,2}$ (1)
}

Received: 29 March 2021 / Accepted: 9 April 2021 / Published online: 17 April 2021

(c) The Author(s), under exclusive licence to Springer Science+Business Media, LLC, part of Springer Nature 2021

For social demands involving energy and environmental problems, various functional materials have been explored. In addition of their intrinsic properties, regulation of nanoscale structures within these materials is often crucial to achieve better performances. Therefore, novel methodologies to construct functional materials from nanoscale units become necessary for further development of useful substances. This task is assigned to an emerging concept, nanoarchitectonics [1-3], which combines nanotechnology with the other research fields including supramolecular chemistry, organic chemistry, materials science, and biorelated technology. Various functional material systems can be produced with the nanoarchitectonics concept using various nano-components such as supramolecular assemblies [4], coordination polymers [5], coordination complexes [6], peptides [7], amino acids [8], and DNAs [9].

In this issue of the Journal of Inorganic and Organometallic Polymers and Materials, nine invited papers on the theme of Nanoarchitectonics for Energy and Environment are presented. This relatively new area of research deals with regulation of internal nanostructures required to achieve high efficiencies and high performances of the functional materials and systems that address energy production and environmental problems. In areas of energy and environmental fields, development of new functional materials is really crucial. As expected, regulation of internal nanostructures of functional materials is sometimes required to achieve high efficiencies and high performances for the target functions.

Katsuhiko Ariga

ARIGA.Katsuhiko@nims.go.jp

1 World Premier International (WPI) Research Center for Materials Nanoarchitectonics (MANA), National Institute for Materials Science (NIMS), 1-1 Namiki, Tsukuba 305-0044, Japan

2 Graduate School of Frontier Sciences, The University of Tokyo, 5-1-5 Kashiwanoha, Kashiwa, Chiba 277-8561, Japan
The nanoarchitectonics concept must have significant contribution to these problems.

This Journal issue contains 3 review articles and 30 research papers. The review articles comprehensively summarize important areas of nanoarchitectonics materials for oxygen reduction and evolution reactions in acidic medium [10], rechargeable batteries with Prussian blue analogs, photo-anode [11], dye and counter cathode in dye-sensitized solar cells [12]. The research articles in the issue cover a wide range of research targets from basic materials productions to various applications in energy and environmental fields. As typical examples, the issue presents (i) adsorption of triclosan onto organically modified-magadiite and bentonite [13]; (ii) production of emulsion-templated photocatalytic porous polymers [14]; (iii) electrochemical properties of sulfur deposited on metal organic frameworks host electrodes [15]; (iv) capacitance performance of Zr-based metal organic framework electrodes [16]; (v) ultrathin Au-Ag heterojunctions on biomimetic substrates for dip catalysis [17]; (vi) effect of tailored hydroxyapatite nanorods on cervical cancer cells [18]; and (vii) copolymer membranes for methylene blue removal [19].

Not limited to these examples, various types of approaches to solve current energy and environmental problems on the basis of the nanoarchitectonics concept are presented. This issue intends to demonstrate the crucial role of nanoarchitectonics to solve socially important issues in energy and environmental fields. Perhaps, it may be even said that the concept of nanoarchitectonics can save our planet.

Katsuhiko, Ariga

Guest, Editor

World Premier International (WPI) Research Center for Materials Nanoarchitectonics (MANA), National Institute for Materials Science (NIMS), 1-1 Namiki, Tsukuba 3050044, Japan. 
Department of Advanced Materials Science, Graduate School of Frontier Sciences, The University of Tokyo, 5-1-5 Kashiwanoha, Kashiwa, Chiba 277-8561, Japan

ARIGA.Katsuhiko@nims.go.jp

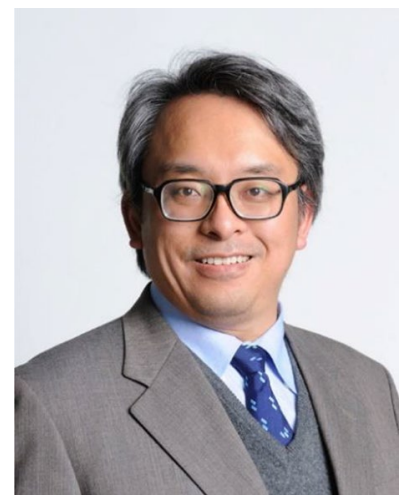

\section{References}

1. K. Ariga, Q. Ji, W. Nakanishi, J.P. Hill, M. Aono, Mater. Horiz. 2, 406 (2015)

2. K. Ariga, Small Sci. 1, 2000032 (2021)

3. K. Ariga, Nanoscale Horiz. (2021). https://doi.org/10.1039/ D0NH00680G

4. K. Ariga, M. Nishikawa, T. Mori, J. Takeya, L.K. Shrestha, J.P. Hill, Sci. Technol. Adv. Mater. 20, 51 (2019)

5. A. Azhar, Y. Li, Z. Cai, M.B. Zakaria, M.K. Masud, M.S.A. Hossain, J. Kim, W. Zhang, J. Na, Y. Yamauchi, M. Hu, Bull. Chem. Soc. 92, 875 (2019)
6. K. Ariga, M. Shionoya, Bull. Chem. Soc. 94, 875 (2021)

7. L. Zhao, Q. Zou, X. Yan, Bull. Chem. Soc. 92, 839 (2019)

8. B. Roy, T. Govindaraju, Bull. Chem. Soc. 92, 1883 (2019)

9. X. Liang, L. Li, J. Tang, M. Komiyama, K. Ariga, Bull. Chem. Soc. 93, $581(2020)$

10. K.R.D. Kasibhatta, I. Madakannu, I. Prasanthi, J. Inorg. Organomet. Polym. (2021). https://doi.org/10.1007/ s10904-020-01834-w

11. Y. Li, Q. Dang, W. Chen, L. Tang, M. Hu, J. Inorg. Organomet. Polym. (2021). https://doi.org/10.1007/s10904-021-01886-6

12. N. Ruba, P. Prakash, S. Sowmya, B. Janarthana, A.N. Prabu, J. Chandrasekaran, T. Alshahrani, H.Y. Zahran, I.S. Yahia, J. Inorg. Organomet. Polym. (2021). https://doi.org/10.1007/ s10904-020-01854-6

13. A. Phuekphong, K. Imwiset, M. Ogawa, J. Inorg. Organomet. Polym. (2021). https://doi.org/10.1007/s10904-021-01919-0

14. A. Vílchez, C. Rodriguez-Abreu, J. Esquena, P.M. Botta, J. Inorg. Organomet. Polym. (2021). https://doi.org/10.1007/ s10904-021-01885-7

15. B.H. Park, Y. Jung, S. Kim, J. Inorg. Organomet. Polym. (2021). https://doi.org/10.1007/s10904-021-01901-w

16. M. Cui, S.J. Park, S. Kim, Inorg. Organomet. Polym. (2021). https://doi.org/10.1007/s10904-021-01935-0

17. V. Karthick, D. Kumar, K. Ariga, C.M.V. Kumar, V.G. Kumar, K. Vasanth, T.S. Dhas, M. Ravi, J. Baalamurugan, J. Inorg. Organomet. Polym. (2021). https://doi.org/10.1007/ s10904-021-01891-9

18. N. Kumari, A. Kumar, V. Krishnan, J. Inorg. Organomet. Polym. (2021). https://doi.org/10.1007/s10904-021-01902-9

19. F. Sciortino, N.M. Sanchez-Ballester, S.H. Mir, G. Rydzek, J. Inorg. Organomet. Polym. (2021). https://doi.org/10.1007/ s10904-021-01971-w

Publisher's note Springer Nature remains neutral with regard to jurisdictional claims in published maps and institutional affiliations. 